\title{
Alchemy and Innovation: Cultivating an Appreciation for Primary Sources in Younger Students ${ }^{1}$
}

IN A TIME OF SEEMINGLY INSTANT ACCESS to information, students are becoming increasingly removed from physical primary source materials. Steve Kolowich explains this disconnection between the original objects and their digital counterparts in this way: "Students might have grown up with the language of the information age, but they do not necessarily know the grammar."” Introducing elementary school students to the differences between primary sources and their digital surrogates is an excellent way to highlight the continued cultural significance of manuscript documents and to foster the development of the critical thinking skills necessary to evaluate media resources in the new information age. Given the evolution of the higher education landscape, dwindling resources, and competing priorities, it could certainly be argued that librarians should concentrate their outreach efforts on the needs of their research and university patrons. However, it remains crucial that special collections libraries demonstrate their rich offerings and promote outreach beyond their walls in an effort to encourage early academic engagement and artifactual literacy in future students while developing vital partnerships within the community at large. Indeed, there appears to be a growing consensus "within the profession that to remain viable in the twenty-first century, special collections need to broaden their reach beyond their traditional reading room base."3 As stewards of primary sources, librarians and archivists are well positioned to help students start down the road to lifelong learning by making manuscripts relevant and personal while transforming special collections institutions from "treasure rooms" to "classrooms." ${ }^{4}$ But, to accomplish this,

1. We would like to thank three anonymous reviewers for providing us with constructive comments and suggestions. Images courtesy of the Lilly Library, Indiana University, Bloomington, Indiana. Photography by Zach Downey.

2. Steve Kolowich, "What Students Don't Know," Inside Higher Ed (Aug. 22, 2011), available online at www.insidehighered.com/news/2011/08/22/erial_study_of_student_research_habits_at_illinois_university_libraries_reveals_alarmingly_poor_information_literacy_and_skills [accessed 14 March 2013].

3. Yolanda Theunissen, "Developing and Promoting Outreach Services for Elementary and Middle Schools: Case Study of a Rare Map Library at a Public University," Journal of Map and Geography Libraries 3, no. 2 (2007): 5-22.

4. Steven Escar Smith, "From 'Treasure Room' to 'School Room': Special Collections and Education," RBM: A Journal of Rare Books, Manuscripts and Cultural Heritage 7, no. 1 (2006): 32-39. 
there are curricular demands, pedagogical standards, and student needs that must be met while protecting the materials and still serving the needs of traditional patrons. We address here ways of connecting young students and special collections so that the teachers' and the students' needs are taken into account and the materials preserved.

Following a brief review of the literature on $\mathrm{K}-12$ outreach in academic special collections, we will outline a program that introduces young students, in our case, to the historical milieu and manufacturing process of medieval manuscripts. We will review the techniques that we employ to prepare students in advance for a visit to Indiana University's rare books and special collections library, The Lilly Library, where students participate in an active learning experience with a variety of medieval and Renaissance materials. ${ }^{5}$ Introducing students to the medieval book as a physical object through self-discovery heuristics and hands-on demonstrations is a unique approach that meets common core standards in such areas as language arts and social studies. The interactive methods outlined can be repurposed to showcase any subject area and collection that an institution chooses to highlight. Participating teachers' evaluations of the outreach program will also be discussed.

\section{The Literature}

A substantial body of literature focuses on the use of primary source materials in undergraduate education. ${ }^{6}$ A recently published collection of essays on undergraduate outreach and special collections, Past or Portal? Enhancing Undergraduate Learning through Special Collections and Archives, stands as a perfect example of the increased interest in expanding the special collections library to include a new generation of patrons beyond the traditional users. As the authors of this collection note, few undergraduates explore rare book rooms or archives. There is an acknowledgement within the literature that special collections materials "offer both distinctive content and opportunities for students to experience learning through direct engagement with rare or unique items, or materials whose arrangement and organization illuminates, instructs, or delights." ${ }^{\prime}$ While not directly discussing $\mathrm{K}-12$ and special collections outreach, much of the advice offered in these articles can be adapted for use with the $\mathrm{K}-12$ population. Visits to special collections, along with specially designed assignments, are used to introduce undergraduates to the research possibilities that exist beyond web browsing, electronic databases,

5. See The Lilly Library, Indiana University, Bloomington, Indiana, available online at www.indiana. edu/ liblilly/index.php [accessed 14 August 2013].

6. Society of American Archivists, Reference, Access and Outreach Section. "Teaching with Primary Sources Bibliography," www.www2.archivists.org/groups/reference-access-and-outreach-section/ teaching-with-primary-sources-bibliography [accessed 14 August 2013].

7. Eleanor Mitchell, Peggy Seiden, and Suzy Taraba, Past or Portal? Enhancing Undergraduate Learning through Special Collections and Archives (Chicago: ACRL, 2012). 
and secondary resources. ${ }^{8}$ An example of such campus outreach efforts is the Yale University Library Traveling Scriptorium kit, created by Yale University Library conservators and curators. The kit, which includes such items as lesson plans, vellum, and pigments, is used to support the study of medieval and early modern books as material artifacts. ${ }^{9}$ The Traveling Scriptorium can be reserved through the Yale University Library Special Collections Conservation Department for use in classrooms across the Yale campus, and classroom visits from conservators and curators can also be arranged.

Comparatively little research or discussion in the professional literature addresses how special collections librarians and archivists can best serve the educational needs of the $\mathrm{K}-12$ population. Articles tend to focus on the role of academic libraries, not special collections and archives, in providing bibliographic instruction and research skills to secondary school students. ${ }^{10}$ This could be attributed in part to the fact that the topic elicits strong feelings among special collections librarians who must balance limited resources, access issues, and preservation concerns. ${ }^{11}$ Only a few scholarly articles on academic special collections mention $\mathrm{K}-12$ outreach, and then it is usually within a more general discussion of the role of special collections. ${ }^{12}$ In his article, "Archivists as Educators: Integrating Primary Sources into the Curriculum," Peter Carini explores various strategies on how best to integrate archival resources into not only the undergraduate curriculum, but into the secondary school classroom as well. ${ }^{13}$ Without a doubt, there is an increasing awareness in the library profession that engaging students of all ages in the use of primary sources (both the physical and digital surrogates) is beneficial in a number of ways-least of which is an appreciation of primary source materials by helping children draw meaningful connections to their own experiences and setting them

8. See Terry Abraham, "Unlocking the Door to Special Collections: Using the Web Combination," Library Philosophy and Practice 3, no. 2 (2011), available online at http://libr.unl.edu:2000/LLP/abraham. html [accessed 14 August 2013]; Stephen Davison, "If We Build It, Will They Come? Strategies for Teaching and Research with Digital Special Collections," RBM: A Journal of Rare Books, Manuscripts and Cultural History 10, no. 1 (2009): 37-49; Deirdre Stam, "Bridge That Gap! Education and Special Collections," RBM: A Journal of Rare Books, Manuscripts and Cultural History 7, no. 1 (2003): 6-30; Susan H. Veccia, Uncovering Our History: Teaching with Primary Sources (Chicago: American Library Association, 2004).

9. Yale University Library, Special Collections Conservation Department, "Traveling Scriptorium: A Teaching Kit by the Yale University Library," available online at http:/ / travelingscriptorium.library.yale. edu/about/ [accessed 14 August 2013].

10. Michelle Visser, "Perspectives on... Special Collections at ARL Libraries and K-12 Outreach: Current Trends," Journal of Academic Librarianship 32, no. 3 (2006): 313-19.

11. Daniel Traister, "Public Services and Outreach in Rare Book, Manuscript, and Special Collections Libraries," Library Trends 52, no. 1 (2003): 87-108; Visser, "Perspectives on... Special Collections at ARL Libraries and K-12 Outreach."

12. Patricia Cleary and David Neumann, "The Challenges of Primary Sources, Collaboration, and the K-16 Elizabeth Murray Project,” History Teacher 43, no. 1 (2009): 67-86; Institute of Museum and Library Services, Charting the Landscape, Mapping New Paths: Museums, Libraries, and K-12 Learning (2005), available online at www.imls.gov/pdf/Charting_the_Landscape.pdf [accessed 14 August 2013].

13. Peter Carini, "Archivists as Educators: Integrating Primary Sources into the Curriculum," Journal of Archival Organization 7, no. 1/2 (2009): 41-50. 
on the path toward lifelong learning. A recent feature in The New York Times highlights an innovative program developed by the Morgan Library and Museum in cooperation with the New York City Department of Education: The Morgan Book Project. The project "aims to instill in children of the digital age an appreciation for books by providing authentic materials to write, illustrate and construct their own medieval and Renaissance-inspired illuminated manuscripts." ${ }^{\prime 4}$ Children (grades 3-7) learn to create their own paints from minerals, vegetables, and insects using traditional methods. The Library of Congress' Teaching with Primary Sources Program (TPS) and its TPS Journal are excellent resources that use LC's collection of digitized primary sources in an effort to help teachers design challenging and engaging classroom exercises and activities around digitized primary source materials..$^{15}$

In his article, "Public Services and Outreach in Rare Book, Manuscript, and Special Collections Libraries," Daniel Traister emphasizes the growing pressure to not only preserve but to actively promote collections, resulting in "a major new element affecting rare book librarians' attitudes." ${ }^{\prime 16}$ Compared with other libraries, Traister asserts that rare book, manuscript, and special collections libraries remain both difficult to access and somewhat forbidding to the casual user. His article considers some of the ways in which promoting special collections to a wider audience has the potential to change for the better the ways in which special collections are both perceived and used. He acknowledges, though, that this is a new and somewhat uncomfortable role for the special collections professional: "If I am right about it, promotion on the scale implicit in the current climate is a relatively new element for rare book libraries and their staffs" ${ }^{\prime 17}$

Michelle Visser echoes Traister's sentiment in her article, "Perspectives on... Special Collections at ARL Libraries and K-12 Outreach: Current Trends," which reports on the results of a survey sent to 115 Association of Research Libraries (ARL) Special Collections requesting information on outreach to K-12 students. Seventy percent of the libraries responded. Just over half of the respondents reported working with $\mathrm{K}-12$. Respondents acknowledged that working with smaller children is often challenging, especially when combined with limited resources and a need

14. Karen Jones, "Teaching Children the Value of Pre-Web Pages," The New York Times (Mar. 14, 2012), available online at www.nytimes.com/2012/03/15/arts/artsspecial/for-children-lessons-in-medieval-manuscript-illumination.html?_r=0 [accessed 15 August 2013].

15. Library of Congress, "Teaching with Primary Sources Annotated Resources Set" (2008), available online at www.mscd.edu/tps/assets/pdf_doc/ARS_template.doc [accessed 14 August 2013]; see also Anne R. Diekema, Heather Leary, Sheri Haderlie, and Cheryl D. Walters, "Teaching Use of Digital Primary Sources for K-12 Settings," D-Lib Magazine 17, no. 3 / 4 (Mar. / Apr. 2011), available online at www. dlib.org/dlib/march11/diekema/03diekema.html [accessed 14 August 2013].

16. Traister, "Public Services and Outreach in Rare Book, Manuscript, and Special Collections Libraries," 88.

17. Ibid., 89 . 
to preserve materials. Yet, as her article demonstrates, the benefits of such visits are tremendously positive and long lasting: "There is also a growing awareness of the unseen benefits that may derive from $\mathrm{K}-12$ visits." ${ }^{18}$ Teachers who had been exposed to special collections as undergraduates were more likely to bring their classes to a special collections library and, as Visser points out, "This would seem to indicate that exposure to special collections can form lasting impressions." ${ }^{19}$ Visser also mentions the 2002 Rare Books and Manuscript Section (RBMS) Preconference, "New Occasions, New Duties: Changing Roles and Expectations in Special Collections," which included a seminar and a few short papers on K-12 outreach. An article by Rita Lipkis titled, "Books in the Classroom: Young Hands on Old Books," documents a very successful, well thought-out public library program that introduces fifth graders to rare books. ${ }^{20}$ Lipkis' article describes both the intellectual and educational approach used as well as the practical details (for instance, the children wear gloves and are divided into small groups).

The push to integrate primary sources and new technologies into the $\mathrm{K}-12$ curriculum is addressed by Anne J. Gilliland-Swetland, Yasmin B. Kafai, and William E. Landis in their article, "Integrating Primary Sources into the Elementary School Classroom: A Case Study of Teachers' Perspectives." ${ }^{21}$ The article reviews effective ways to incorporate primary sources in the classroom as well as surveying teachers' attitudes concerning the use of primary sources. Similarly, Kelly Kerbow Hudson, in "The Gloria Anzaldúa Archive as Teaching Tool: A Look at Lesson Planning for Elementary School Students," surveys current trends in using primary resources for $\mathrm{K}-12$ education. ${ }^{22}$

Yolanda Theunissen's "Developing and Promoting Outreach Services for Elementary and Middle Schools: Case Study of a Rare Map Library at a Public University" addresses many of the struggles faced by special collections librarians when trying to strike a balance between preservation and access to their collections. ${ }^{23} \mathrm{Her}$ article provides an interesting look at two successful K-8 student programs developed and promoted at the Osher Map Library and Smith Center for Cartographic Educa-

\footnotetext{
18. Visser, "Perspectives on... Special Collections at ARL Libraries and K-12 Outreach," 317.

19. Ibid.

20. Rita Lipkis, "Books in the Classroom: Young Hands on Old Books," Horn Book Magazine 69, no. 1 (1993): 115-18.

21. Anne J. Gilliland-Swetland, Yasmin B. Kafai, and William E. Landis, "Integrating Primary Sources into the Elementary School Classroom: A Case Study of Teachers' Perspectives," Archivaria 1, no. 48 (1999): 89-116; see also Anne J. Gilliland-Swetland, "An Exploration of K-12 User Needs for Digital Primary Source Materials,” American Archivist 61, no. 1 (1998): 136-57.

22. Kelly Kerbow Hudson, "The Gloria Anzaldúa Archive as Teaching Tool: A Look at Lesson Planning for Elementary School Students," Journal for the Society of North Carolina Archivists 9, no. 1 (2011): 25-34; see also Anne Diekema, "Teaching Use of Digital Primary Sources for K-12 Settings," D-Lib Magazine 17, no. 3 / 4 (2011), available online at www.dlib.org/dlib/march11/diekema/03diekema.html [accessed 13 August 2013].

23. Theunissen, "Developing and Promoting Outreach Services for Elementary and Middle Schools."
} 
tion, a rare map library at the University of Southern Maine. In addition to school group tours, Theunissen discusses the use of traveling teaching kits that include lesson plans, slides, and facsimile maps. The kits are loaned to local schools free of charge for extended periods.

\section{Building the Bridge: A Three-Step Approach}

Primary source materials, when tethered and integrated into a structured lesson plan, can help to foster student inquiry and critical thinking skills. Artifactual literacy, one of the important skills we want to reinforce with this approach, helps to make students aware of the existence of primary sources and how they are different from, but relate to, secondary sources. Often it is necessary to define and introduce resources in a way that builds on prior knowledge while introducing new facts. With this in mind, we create an age-appropriate vocabulary list and a variety of preparatory activities for use in the classroom that are designed to prepare students for their visit to the Lilly Library (Appendices 1 and 2). About one month prior to the actual class visit to the library, in addition to the vocabulary list, we provide the teachers with activities and resources selected to introduce students to how books were made during the Middle Ages (Appendix 3). In an effort to place medieval manuscripts in a greater context, we provide a CD of selected medieval songs, worksheets that introduce medieval scriptorium tools, and age-appropriate books on the making of medieval manuscripts (see Appendices). In the school environment, students approach concepts, ideas, and problems differently, according to their backgrounds and personal experiences. Our goal is to provide a common vocabulary and contextual setting from which students can draw. Heuristic procedures such as listing, brainstorming, and worksheets can guide inquiry and stimulate memory and intuition. ${ }^{24}$

The second step involves an hour-long visit to the classroom. About a week before the trip to the Lilly Library, after each class has had time to complete the assigned activities, we meet with the students to review and reinforce what they have already learned. Through an image-rich Power Point presentation that we are careful to keep short, we review how manuscripts were made and demonstrate such things as cutting quill pens, making ink, and gold leafing. The digital images in the Power Point are of the same Lilly Library manuscripts that the students will see on their visit. In addition, the images are housed and available for the classroom teacher's use in The Digital Scriptorium (hosted at the Bancroft Library). ${ }^{25}$ The Digital Scriptorium is a growing image database of medieval and Renaissance manuscripts that

24. Janice M. Lauer, "Heuristics," Encyclopedia of Rhetoric and Composition: Communication from Ancient Times to the Information Age, ed. Theresa Enos (New York: Routledge, 2010).

25. The Digital Scriptorium, available online at http://bancroft.berkeley.edu/digitalscriptorium/ [accessed 14 August 2013]. 
unites scattered resources from many institutions, including the Lilly Library, into an international tool for teaching and scholarly research. We also bring a variety of scriptorium supplies for the students to examine (such as feathers, shell gold, pigments and binders, a leaf of vellum, oak galls). Following the presentation, students create their own personal illuminated initial, at times embellished with items of interest to them, such as soccer balls, family pets, and the like. These interactive teaching techniques help students to appreciate, comprehend, and retain historical information on the costly, lengthy, and arduous task of creating an illuminated manuscript. The activities also teach both students and teachers the significance of primary source materials to the historical record and, perhaps even more important, teach students how to find, analyze, and evaluate web content in an increasingly media-saturated society. ${ }^{26}$

The importance of these previsit activities cannot be overestimated. They prepare students for what may be their first visit to a museumlike setting and, certainly for most, their initial visit to a rare books and manuscript venue. In addition to laying the groundwork for a common vocabulary and a shared knowledge with which to talk about the materials, it also helps to prepare the students for some behavioral expectations such as "please look but don't touch," letting us add, "but we're happy to turn many pages for you," while they are still in their familiar classroom setting. It is important also to make clear beforehand to the teacher exactly how the visit will unfold, which helps to diminish some of the traditional barriers to using primary source materials, particularly with this age group. ${ }^{27}$

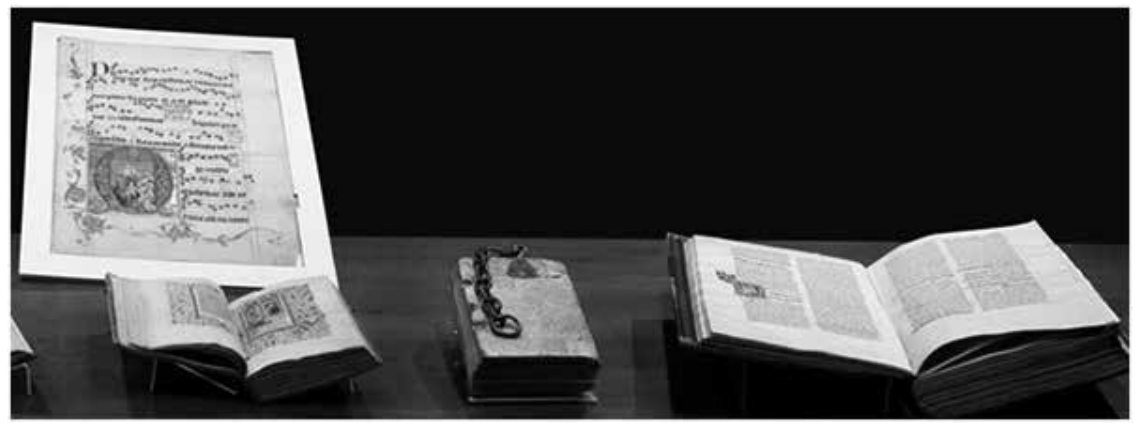

Figure 1. A selection of medieval manuscripts. Image courtesy of the Lilly Library, Indiana University, Bloomington, Indiana. Photography, Zach Downey.

Upon arrival at the Lilly, the students are divided into two smaller groups. One group views a selection of medieval manuscripts (see figure 1) while the other

26. Peggy Sands Orchowski, "Library of Congress in Digital Age Gives Teachers Access to All Knowledge," Education Digest 75, no. 4 (Dec. 2009): 45-46.

27. Stam, "Bridge That Gap!" 22. 
half of the class views either selections from the Lilly Library's mechanical puzzle collection or popup books collection. After approximately 30 minutes, the groups change places.

Just to take the edge off the need to touch and to ensure an early tactile experience, we start the visit to the medieval manuscripts by allowing the students to handle, smell, and pass around a prepared piece of vellum, while pointing out the differences between the hair and flesh side and the presence of any spots or blemishes, and encouraging them to share what they remember about how vellum is prepared. We have three pieces of vellum-one a contemporary skin and two 15th-century binding fragments - that were purchased specifically for this purpose.

In selecting materials to be displayed, we are careful to choose items that have no current preservation or conservation concerns (such as bindings sturdily attached and intact, a book that opens comfortably and wide enough so that the students can easily see inside, and/or no loose or detached leaves). Codices of unusual sizes, such as a charmingly illustrated miniature Book of Hours, the remarkable fragment of a chained binding, and a heavily bossed antiphonal are among the items usually selected for exhibition to illustrate what a digital image really cannot-the physical differences between different types of books.

We choose images, fragments, and codices that are effective for each specific age group, selecting those that may be both whimsical as well as more complex, depending upon the age group with which we are working and their background. In addition, images depicting the medieval scribe engaged in various writing practices and writing with a penknife in one hand and a quill in the other are selected when possible, reinforcing the classroom demonstrations.

The Lilly Library houses many single leaves and fragments that offer opportunities for a discussion of "broken books" and a chance to ponder some of the reasons codices might have been disbound. Small cuttings demonstrate that often just the initials were cut out individually as well as an entire leaf. A single leaf from a very large and sumptuous 15th-century antiphonal, for example, serves a dual purpose. Not only is it a spectacular example of illumination, it is also a representation of medieval musical notation. Students who have had some musical training often comment on the shape of the musical signs (square notation) and offer explanations or thoughts about how it might have been to sing together from such a book.

Books of Hours are another genre of medieval texts that is particularly effective for introducing elementary school children to manuscript materials of the era. Highly visual, they provide an opportunity for many discussion points: the notion of lit- 
eracy, the use of images to illustrate stories and reinforce desired behaviors as well as commonly understood and shared religious iconographies of the middle ages. We choose items that are strikingly illustrated and heavily illuminated—going for the maximum WOW factor.

Marginal images, whether grotesque, naturalistic, or fanciful, are a constant source of amusement and intrigue. Having previously completed a coloring sheet scavenger hunt looking for scribal tools in one of their classroom activities, seeing the animals and figures commonly depicted in the intricate margins of many medieval manuscripts quickly engages them in repeating the hunt. The students enjoy discovering these unique characters, such as an appealing little owl or a taunting figure attempting to distract the scribe from his work.

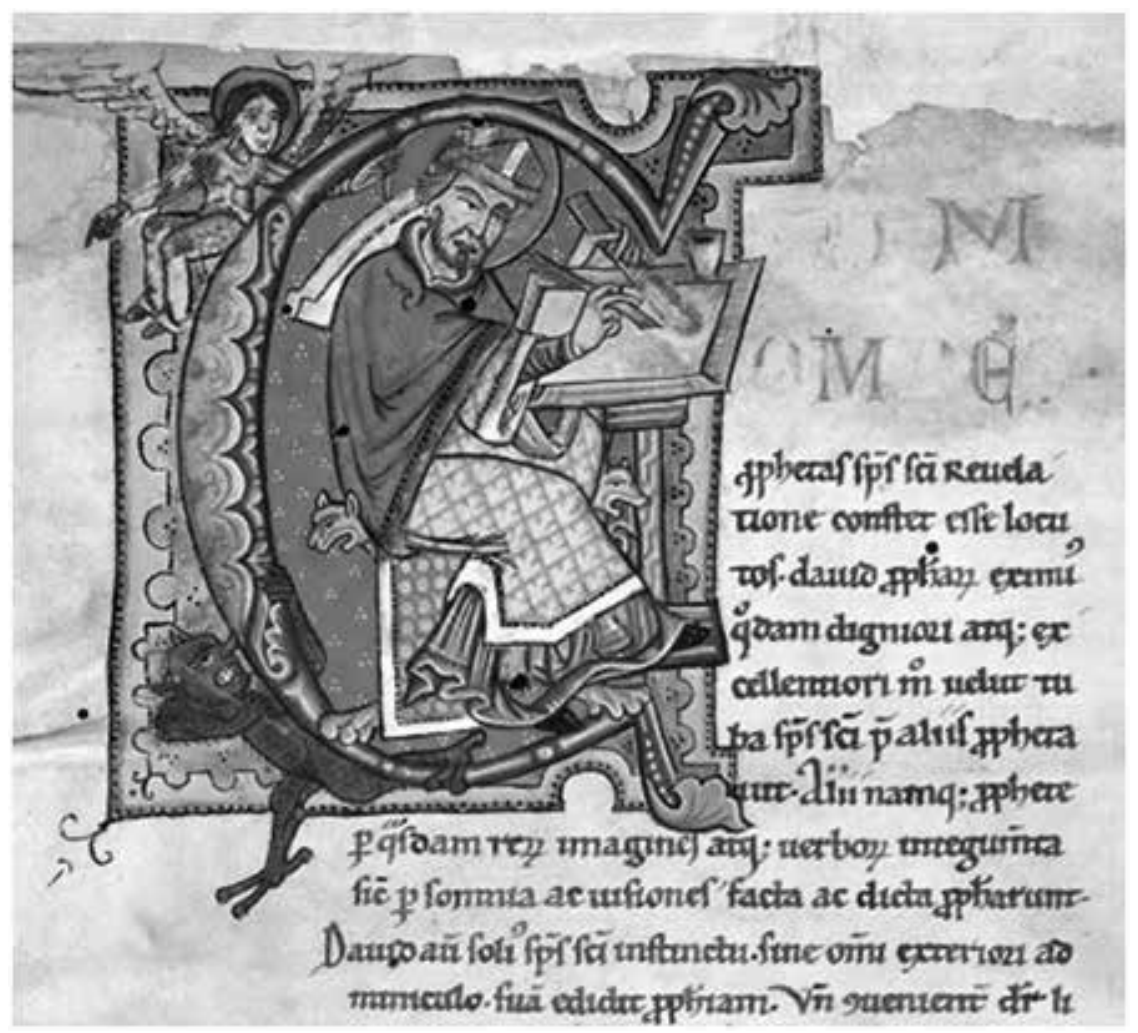

FIGURE 2. A Bishop writing (early 13th century), Ricketts 20. Image courtesy of the Lilly Library, Indiana University, Bloomington, Indiana. Photography, Zach Downey.

\section{Learning and Outreach}

Introducing younger students to the world of special collections is not without work and effort on the part of everyone involved. To date, we have worked with over 300 students and their teachers. Although carefully coordinating with the 
classroom teacher to create quality instructional content and planning the in-class visit can be both time consuming and challenging, it is vital that both parties know what to expect so that a positive experience is created for the students, teachers, and library staff. The previsit learning activities - the in-class instruction and preparation-combine to make the actual library visit a more satisfying experience for everyone involved. The investment in a collection of tangible teaching materials allows students to touch and interact with items and helps with the temptation to touch the rare materials. ${ }^{28}$ The time commitment and designated resources result in many positive benefits for the special collections institution involved-meeting the education mission in new ways through community outreach, increased visibility, showcasing collections to a new audience, and a new patron base, even perhaps inspiring the development of a budding collector!

The teachers we have partnered with in grades 3-8 have provided consistently positive feedback and often mention that the classroom visit laid a foundation of previsit learning for the students to build upon. Teachers appreciate that, prior to the visit, the students know exactly what the library's expectations are and what they will see. Students learn vocabulary, engage in previsit learning activities, and are introduced to the rare book and special collections library's particular rules and expectations in their own familiar classroom setting. The classroom visit should not last more than one hour and should include some sort of show-and-tell activities. Students should be allowed to handle materials, ask questions, and share what they have learned.

When they arrive at the library on the day of their visit, teachers report that students are more confident as a result of the previsit learning activities and feel empowered as they recall prior information from the in-class visit. Breaking the classes into smaller groups allows us to monitor the students so that materials are protected. However, the need for formal assessment measures and tools cannot be dismissed. In their recent article, Anne Bahde and Heather Smedberg note that while "The library literature on assessment techniques for information literacy instruction (ILI) is rich, much less has been documented within special collections and archives literature." 29 Though the use of rubrics to measure the effectiveness of special collections and $\mathrm{K}-12$ outreach education programs would be advantageous to include, it remains an area of future exploration for this project.

28. In addition to arts and crafts stores, online resources for purchasing supplies include: Talas, available online at www.talasonline.com/ [accessed 14 August 2013]; Kremer Pigments Inc. New York, available online at www.kremerpigments.com/ [accessed 14 August 2013]; John Neal Bookseller, available online at www.johnnealbooks.com/ [accessed 14 August 2013]; Natural Pigments, available online at www.naturalpigments.com/ [accessed 14 August 2013]; L.Cornelissen \& Son, available online at www. cornelissen.com/ [accessed 14 August 2013]; The Woolery: Fiber Arts Supplier, available online at www. woolery.com/store/pc/home.asp [accessed 15 August 2013].

29. Anne Bahde and Heather Smedberg, "Measuring the Magic," RBM: A Journal of Rare Books, Manuscripts and Cultural History 13, no. 2 (Fall 2012): 152-74. 


\section{Extending the Bridge to New Opportunities}

While the incredible artistry and creativity demonstrated in medieval manuscripts, whatever their original function or their format, rarely fails to delight the imagination and engage a sense of wonder in these young students, we are also exploring ways in which to expand our activities to include artists' books as well as popup books or "paper engineering." Both genres lend themselves to the three-part program we have developed-previsit learning activities within the home classroom including a digital image-rich Power Point followed by a hands-on visit to the Lilly Library for an introduction to the physical artifact itself. These are but two suggestions from our collections, but we feel that the activities suggested here lend themselves to many different kinds of collections and activities geared to the resources and treasures of local repositories, whether public or academic.

The Lilly Library's longstanding and notable commitment of providing access to its collections to the dedicated scholarly research community as well as to the interested general public bodes well for the future of rare books and manuscripts as physical objects in an ever-evolving digital environment. Combining this demonstrated commitment to the principles of access for patrons of all kinds allows us to form new cooperative liaisons with campus and community partners and, as Traister explains, "such projects, if well-conceived, almost sell themselves." ${ }^{30}$ Making the effort to work with a more diverse community of users is sure to engender goodwill and greater visibility for the participating institution as we revise our roles as information specialists in the 21 st century.

30. Traister, "Public Services and Outreach in Rare Book, Manuscript, and Special Collections Libraries," 93. 


\section{Appendix 1: Previsit Learning Activities}

Scriptorium Tools Color Sheet Example ${ }^{31}$
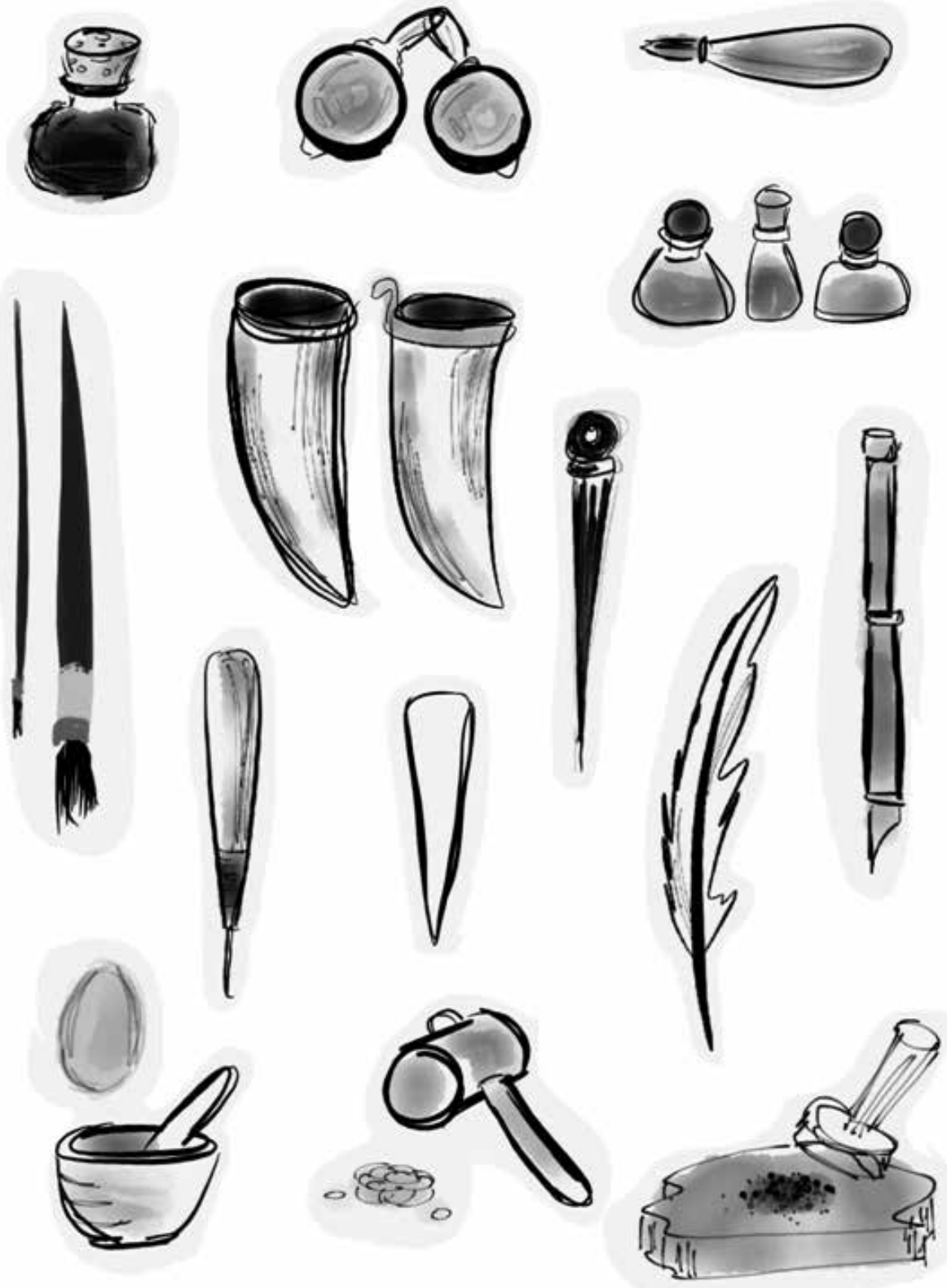

31. Special thanks to Courtney Brombosz for these illustrations. 


\section{Appendix 2: Previsit Learning Activities \\ Medieval Manuscripts \\ Selected Vocabulary}

Illuminate: To decorate (a manuscript, book, etc.) with colors and gold or silver, as was often done in the Middle Ages.

Oak gall ink: A purple-black or brown-black ink made from iron salts and tannic acids from vegetable sources. It was the standard writing and drawing ink in Europe, from about the 12th century to the 19th century, and remained in use well into the 20th century (also known as iron gall nut ink or oak gall ink).

Manuscript: A "manuscript" is a book written and produced by hand. During the Middle Ages, before printing in the fifteenth century, all books were manuscripts.

Middle Ages: Medieval times (also called the Middle Ages) refers to a block of time in history from 500 A.D. to about 1500 A.D.

Monastery: A house or place of residence occupied by a community of persons, especially monks, living in separation from the outside world under religious vows.

Monk: $\quad$ (In Christianity) a man who has withdrawn from the world for religious reasons, especially as a member of monastery according to a particular rule and under vows of poverty, chastity, and obedience.

Parchment: The skin of sheep, goats, etc., prepared for use as a material on which to write.

Quill pen: A feather (for example, from a goose) formed into a pen for writing.

Script: $\quad$ The letters or characters used in writing by hand; handwriting, especially cursive writing; a manuscript or document.

Scriptorium: A room, as in a monastery, library, or other institution, where manuscripts are stored, read, or copied.

Scoring: A notch, scratch, or cut; a line.

Vellum: $\quad$ Calfskin, lambskin, goatskin, etc., treated for use as a writing surface. 


\section{Appendix 3: Previsit Learning Activities}

\section{Medieval Manuscripts}

Books were very expensive in medieval Europe, so there weren't very many of them. Each book had to be written by hand by a trained scribe (often a monk for most of the Middle Ages), and that took a long time. Each book had to be written on parchment, which was very expensive, too. People who had books took very good care of them. Sometimes library books were chained to the tables so people could not steal them (the way we put security sensors in library books today).

Parchment is made from animal skins. Usually people used the skins of sheep or cows, because those animals were pretty common in Europe. You took the skin and scraped off all the hair from the outside and all the fat from the inside. Then you soaked the skin in water with chalk or flour and salt added to give it a good smooth surface to write on. And finally you soaked the skin in tannin made from oak-gall, to preserve it (like pickling something).

By about $800 \mathrm{AD}$, even the Egyptians weren't using papyrus anymore, because they had learned about the Chinese invention of paper, which was much cheaper. All over the Islamic Empire, people were using paper-and writing a lot! But in Europe people were still using parchment, and writing as little as possible.

In the 1200s, though, Europeans conquered some Islamic territory in Spain, and captured a paper mill. They learned how to make paper, and within two hundred years nobody was really using parchment anymore except for special things like diplomas and letters between nobility.

\section{Selected Bibliography \& Websites}

Jonathan Hunt, Illuminations (Fullerton, Calif.: Aladdin Books, 1993)

David Macaulay, Castle (Boston, Mass.: Houghton Mifflin, 1982)

Theodore Menten, The Illuminated Alphabet (New York: Dover, 1971)

C.M. Millen, The Ink Garden of Brother Theophane (Watertown, Mass.:

Charlesbridge, 2010)

W. Nikola-Lisa, Magic in the Margins (Boston, Mass.: Houghton Mifflin, 2007)

Margot McIlwain Nishimura, Images in the Margins (Getty Museum/British Library, 2009)

Bruce Robertson, Marguerite Makes a Book (Los Angeles, Calif.: Getty Museum, 1999)

Andi Stix, Medieval Times (Huntington Beach, Calif.: Teacher Created Materials, 2003) 
Cross-Curricular Ideas: Art, Trade, Development. The National Gallery

(London). http://www.nationalgallery.org.uk/learning/teachers-andschools/picture-in-focus/cross-curricular-ideas/art-trade

The Making of a Medieval Book. The J. Paul Getty Museum. http://www. getty.edu/art/gettyguide/videoDetails?segid $=3728$ segnr $=5$

Natural Organic Pigments. http://handprint.com/HP/WCL/pigmt1c.html

Leaves of Gold: Treasures of Manuscript Illumination from Philadelphia

Collections. http://leavesofgold.org/learn/index.html

\section{Appendix 4: Outline of In-Class Visit for Teacher}

\section{Third Grade Class Visit Outline ${ }^{32}$}

\section{Introduction}

II. Discuss surrogate digital images $\&$ review scriptorium tools

III. Medieval manuscripts first made in monasteries then gradually moved to become a business outside of the Church

a. Notice the windows, desks (slanted), no copy machine!; books read out loud and everyone copies at the same time on occasion

IV. What to write on? No paper in the West yet, but lots of sheep and cows vellum $\&$ parchment
a. Preparing \& cutting
b. Ruling
c. Preparing the layout
d. Mistakes? No erasers, so you scrape ink off

V. Something to write with-quills and ink
a. Quills
b. Lampblack (show)
c. Gall ink (show) - video (4 minutes)

VI. Decorations - colors and gold, silver, copper leaf (You might go to the "pharmacy" [apothecary] to get your pigments.)
a. Show pigments
b. Gold leaves - very expensive-demonstrate
c. Egg whites used as adhesive

Pre-library visit activity

Color your own illumination, but remember, for your initial to be a true "illumination," you must use gold somewhere!

\footnotetext{
32. Some of the supplies that can be brought to the class include:

Vellum Awl Reed tube Pigments Lampblack Candle/Matches Gum Arabic

Ground Gum Arabic Paint brushes Gold leaf Egg Gold leaf Iron oak galls Quills
} 